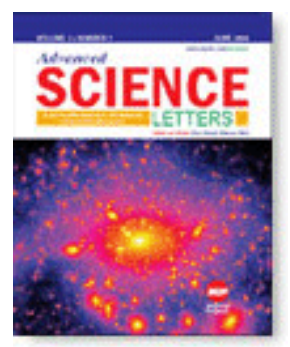

\title{
Islamic English in Maher Zain's Songs: Is There a Need?
}

Buy Article:

$\$ 106.23+$ tax

(Refund Policy)

ADD TO CART

BUY NOW

Authors: Othman, Khairiah; Malik, Faridah Abdul

Source: Advanced Science Letters, Volume 23, Number 5, May 2017, pp. 5007-5010(4)

Publisher: American Scientific Publishers

DOI: https://doi.org/10.1166/asl.2017.8997

\begin{tabular}{|l|l|l|l|}
\hline Abstract & $\begin{array}{l}\text { References } \\
\text { Citations }\end{array}$ & $\begin{array}{l}\text { Supplementary Data } \\
\text { Article Media }\end{array}$ \\
A significant rise in the number of English-speaking Muslims around the world calls for more attention on the \\
proper usage of Islamic terms in the English language. Popularized by al-Faruqi, Islamic English refers to the \\
English language modified to enable Muslims to carry Islamic proper names, nouns, meanings and concepts \\
without distortion. This article aims to highlight the need for Islamic English to be used particularly for Muslims. \\
The study employed content analysis method in examining Islamic terms and concepts utilized by Maher Zain \\
in his English Islamic songs. The findings indicate the presence of Arabic words and concepts in his songs \\
mainly due to the absence of equivalent English words, lack of accurate translation and a form of worship, \\
hence the need for Islamic English.
\end{tabular}

Keywords: Islamic English; Maher Zain; Songs; Varieties of English; World Englishes

Document Type: Research Article

Affiliations: Centre for Languages and Pre-University Academic Development, International Islamic University Malaysia, Jalan Gombak, 53100 Kuala Lumpur, Malaysia

Publication date: May 1, 2017

More about this publication? 